\title{
Pixantrone demonstrates significant in vitro activity against multiple myeloma and plasma cell leukemia
}

\author{
Ella Willenbacher ${ }^{1} \cdot$ Karin Jöhrer $^{2} \cdot$ Wolfgang Willenbacher $^{1,3} \cdot$ Brigitte Flögel $^{1,2} \cdot$ Richard Greil $^{2,4} \cdot$ Brigitte Kircher $^{1,2}$ (D)
}

Received: 8 February 2019 / Accepted: 8 September 2019/Published online: 18 October 2019

(C) The Author(s) 2019

\begin{abstract}
Treatment results for multiple myeloma and plasma cell leukemia have considerably improved, but cure remains elusive and establishing new therapeutic approaches constitutes a major unmet clinical need. We analyzed the anti-myeloma properties of the aza-anthracenedione pixantrone which has been successfully used in a phase III study for the treatment of patients with aggressive non-Hodgkin's lymphoma as monotherapy as well as in combination regimes in vitro and in an adapted in vivo model (ex ovo chicken chorioallantoic membrane (CAM) assay). Pixantrone significantly inhibited proliferation and metabolic activity of all investigated myeloma cell lines. Importantly, anti-myeloma effects were more pronounced in tumor cell lines than in stromal cells, mesenchymal stem cells, and peripheral blood mononuclear cells of healthy controls. Apoptosis of myeloma cell lines was observed only after a 7-day incubation period, indicating a fast cytostatic and a slower cytotoxic effect of this drug. Pixantrone reduced the viability of primary plasma cells of patients and induced downregulation of myeloma-cell growth in the CAM assay. Additionally, we demonstrate in vitro synergism between pixantrone and the histone deacetylase inhibitor panobinostat with respect to its anti-proliferative features. From these data, we conclude that systematic investigations of the clinical usefulness of pixantrone in the framework of controlled clinical trials are clearly indicated (e.g., in penta-refractory patients).
\end{abstract}

Key words Multiple myeloma $\cdot$ Plasma cell leukemia $\cdot$ Pixantrone $\cdot$ Anti-myeloma activity $\cdot$ Drug screening

\section{Introduction}

Multiple myeloma (MM) is an incurable malignant disease of immunoglobulin and/or free light chains producing

Ella Willenbacher and Karin Jöhrer contributed equally to this work.

Electronic supplementary material The online version of this article (https://doi.org/10.1007/s00277-019-03797-6) contains supplementary material, which is available to authorized users.

Brigitte Kircher

Brigitte.Kircher@i-med.ac.at

1 Internal Medicine V (Hematology \& Oncology), Medical University of Innsbruck, Anichstr. 35, 6020 Innsbruck, Austria

2 Tyrolean Cancer Research Institute, Innsbruck, Austria

3 Oncotyrol, Center for Personalized Cancer Medicine, Innsbruck, Austria

4 Department of Internal Medicine III, Laboratory for Immunological and Molecular Cancer Research, Paracelsus Medical University Salzburg, Salzburg, Austria monoclonal plasma cells, clinically characterized by hypercalcemia, renal failure, anemia, and osteolytic bone disease (socalled CRAB criteria). Considerable clinical progress has been made with respect to higher response rates, better remission-induction efficiency and depth, as well as the improvement of both progression-free and overall survival. However, cure remains an elusive therapeutic goal. Nearly all patients will sooner or later relapse and develop treatment resistance to all available drugs and treatment modalities [1]. Median survival has improved to 7.3 years in cytogenetically defined standard risk patients [2,3], but can be estimated at less than 2 years in patients harboring combined clinical and genetic risk factors $[4,5]$. So-called penta-refractory MM (refractory to bortezomib, carfilzomib, lenalidomide, pomalidomide, and anti-CD38 antibodies) harbors a dismal prognosis with a median survival below 6 months [6].

Plasma cell leukemia (PCL) is a leukemic variant of myeloma arising either de novo or from clinically preexistent $\mathrm{MM}$ in mostly heavily pretreated patients and carries an even worse prognosis than does relapsed/ refractory MM. Treatment options are limited, and no drug has ever been explicitly registered for this indication. 
Furthermore, there is no generally accepted standard of care, although most hematologists use-depending on previous treatments - combinations of MM drugs, steroids, and chemotherapy [7]. Anthracyclines such as doxorubicin (adriamycin) are among the most active classical drugs in lymphoma and myeloma therapy, but their use is limited by cumulative and irreversible cardiotoxicity. With respect to MM therapy, anthracyclines are typically used in combination regimes like bortezomib/adriamycin/dexamethasone (PAD) [8] or bortezomib and pegylated liposomal doxorubicin (B-lipA) [9] and lenalidomide, adriamycin, and dexamethasone (RAD) [10] that combine classical chemotherapy with "novel agents" such as proteasome inhibitors and immune-modulatory drugs (IMiDs).

Pixantrone (PIX) is structurally similar to the anthracycline doxorubicin (Dox), but with an improved toxicity profile, especially with regard to cardiotoxicity [11, 12], while maintaining anti-tumor activity $[13,14]$. A phase III clinical trial in massively pretreated aggressive non-Hodgkin's lymphoma patients led to the drug's conditional approval in the EU [15]. The classical mode of action of PIX has long been considered to be DNA binding and inhibition of topoisomerase II, an enzyme that is involved in DNA replication [16]. In contrast to classic anthracyclines, PIX has been shown to act selectively on the topoisomerase isoform Ii $\alpha$ [11]. Recently, an additional - quite unique - mechanism of action for inducing cell death, nicknamed induction of "mitotic catastrophe" by mitotic perturbations and subsequent aberrant cell divisions, was described for PIX [17]. Furthermore, a synergistic interaction of proteasome and topoisomerase II inhibition on MM cell lines has been published [18]. These features render the drug a promising candidate, not only for clinical development in aggressive non-Hodgkin's lymphomas, but also in the still not investigated field of MM.

Here, we investigated the anti-myeloma properties of PIX by (1) analyzing its effects on myeloma cell lines, (2) screening in vitro for anti-myeloma synergisms with putative combination partners, (3) confirming its antimyeloma effect in a chorioallantoic membrane assay (CAM), and finally (4) generating confirmatory evidence with primary patient material.

\section{Patients}

All patients gave written informed consent to the use of their biologic materials for research (EU FP7 consortium OPTATIO) and documentation of their clinical data via the Austrian Myeloma Registry (AMR) after extensive discussion of the respective procedures.

Patient disposition is outlined in Table 1.
Table 1 Patient disposition

\begin{tabular}{lllll}
\hline Patient & Age (a) & Sex & Disease status & Isotype \\
\hline 1 & 61 & F & Secondary PCL & FLC kappa \\
2 & 64 & F & Secondary PCL & IgM kappa \\
3 & 63 & F & Secondary PCL & IgG lambda \\
4 & 70 & M & PCL & FLC kappa \\
5 & 64 & M & PCL & IgG kappa \\
6 & 49 & M & RRMM & IgG lambda \\
7 & 70 & M & RRMM & IgA kappa \\
\hline
\end{tabular}

$a$, years; FLC, free light chain; Ig, immunoglobulin; $P C L$, plasma cell leukemia; $R R M M$, relapsed/refractory multiple myeloma

\section{Methods}

\section{Cell culture}

Myeloma cell lines (KMS-12-BM, KMS-12-PE, LP-1, RPMI-8226, AMO-1, OPM-2, U-266; purchased from German Collection of Microorganisms and Cell Cultures (DSMZ, Braunschweig, Germany)) and the stromal cell line HS-5 (from ATCC, Manassas, USA) were cultured in RPMI 1640 without phenol red, supplemented with L-glutamine (2 $\mathrm{mM})$, penicillin $(100 \mathrm{U} / \mathrm{mL})$, streptomycin $(100 \mu \mathrm{g} / \mathrm{mL})$, and fetal calf serum (FCS, $10 \%$ or $20 \%$; all from PAA Laboratories, Pasching, Austria). Cells were cultured at 37 ${ }^{\circ} \mathrm{C}$ in a humidified atmosphere containing $5 \% \mathrm{CO}_{2}$. The cells were serially passaged twice a week. All cell lines were authenticated by typing short tandem repeats. Mycoplasma contamination was routinely monitored and only mycoplasmafree cultures were used. Mesenchymal stem cells were purchased from PromoCell (Heidelberg, Germany) and cultured in Mesenchymal Stem Cell Growth Medium, according to the manufacturer's instructions.

\section{Preparation of peripheral blood mononuclear cells (PBMC) and primary patient material}

PBMC from two patients with de-novo PCL, three patients with secondary PCL, and two patients with relapsed/refractory MM as well as four healthy volunteers were isolated by Ficoll density gradient centrifugation. To generate activated PBMC cells $\left(5 \times 10^{4}\right)$ were incubated with $1 \mu \mathrm{g} / \mathrm{mL}$ phytohemagglutinin (PHA; Sigma-Aldrich, Vienna, Austria) and appropriate concentrations of PIX for $72 \mathrm{~h}$.

\section{Analysis of proliferation}

The rate of cell proliferation was measured by labeling with $\left[{ }^{3} \mathrm{H}\right]$-thymidine as previously described [19]. Proliferation in the absence of the compounds was set at $100 \%$, and the drug's 
activity was calculated as percentage of the control (without compound).

\section{Measurement of metabolic activity}

Metabolic activity was determined by measuring the reduction of tetrazolium salts to formazan derivatives using a modified 3-(4,5-di-methyl-thiazol-2-yl)-2,5-diphenyltetrazolium bromide (MTT) assay (EZ4U kit; Biomedica, Vienna, Austria) according to the manufacturer's instructions. To exclude unspecific staining by FCS-containing medium, the optical density (OD) of the respective medium was subtracted. Metabolic activity in the absence of the compounds was set at $100 \%$.

\section{Apoptosis assays}

Induction of programmed cell death for cell lines and primary cells after different time periods was determined by staining with Annexin V (Ann V)-FITC-labeled antibody and propidium iodide (PI). Samples were further analyzed by flow cytometry (FACS Canto, BD Bioscience, San José, CA, USA) and data were evaluated utilizing FlowJo software (LLC, Ashland, OR, USA).

\section{Ex ovo chicken chorioallantoic membrane assay (CAM assay)}

The CAM assay used in this study was essentially performed as described previously [20]. In detail, collagen onplants containing green fluorescent protein (GFP)-transfected myeloma cells were transferred to opened, fertilized, white leghorn chicken eggs and cultured on their chorio-allantoic membrane with/without the addition of PIX $(1 \mu \mathrm{M})$. Xenotransplants were microscopically analyzed (Olympus SZX10, Olympus, Vienna, Austria) on day 5. Thereafter, onplants were excised, protein was prepared, and tumor load was determined using anti-GFP ELISA (eBioscience, Thermo Fisher Scientific, Vienna, Austria).

\section{Statistical analysis}

The Wilcoxon rank-sum test was used to analyze the differences between proliferation, metabolic activity, and apoptosis induction in the absence and the presence of the respective concentration of the compounds (NCSS software, Kaysville, UT, USA). A $p$ value $<0.05$ was considered statistically significant. Additive and synergistic effects of drugs were defined according to the following formula: additive mode of action: surviving fraction (SF) (compound $\mathrm{A}+$ compound $\mathrm{B})=\mathrm{SF}(\mathrm{A}) \times \mathrm{SF}(\mathrm{B})$; synergistic mode of action: $\mathrm{SF}(\mathrm{A}+$ B) $<\mathrm{SF}(\mathrm{A}) \times \mathrm{SF}(\mathrm{B})[21]$.

\section{Results}

\section{Effect of PIX on myeloma cell line proliferation}

Proliferation of myeloma cell lines was determined after $72 \mathrm{~h}$ of incubation with various concentrations of PIX. All cell lines tested showed reduced proliferation, and the extent was dosedependent, starting at $0.05 \mu \mathrm{M}$ PIX (Fig. 1a). At a PIX concentration of $0.25 \mu \mathrm{M}$, proliferation was inhibited to $14.0 \pm$ $3.2 \%$ (AMO-1, highest responding cell line) and $28.2 \pm 4.2 \%$ (KMS-12-BM, lowest response). From these data, we assume the IC50 for proliferation inhibition between 0.1 and $0.25 \mu \mathrm{M}$. Strikingly, non-MM cells such as the stroma cell line HS-5, mesenchymal stem cells, and PBMC from healthy donors activated with phytohemagglutinin were significantly less affected (average proliferation $67.0 \pm 7.3 \%$ ).

As PIX structurally resembles Dox, a drug still widely used for MM treatment, the anti-proliferative capacity of Dox was analyzed in parallel in selected myeloma cell lines after a 72-h incubation. As shown in Fig. 1b, Dox displayed stronger activity on the myeloma cell lines than PIX. The IC50 for proliferation inhibition was, except for KMS-12-BM, approximately $0.01 \mu \mathrm{M}$. After incubation with a concentration of $0.05 \mu \mathrm{M}$ Dox, almost no proliferation was detected.

Similar anti-proliferative effects of PIX were observed in a co-culture system with the stromal cell line HS-5 (data shown in Supplemental File).

\section{Effect of PIX on MM cell metabolic activity}

To test whether the strong anti-proliferative activity of PIX resulted also in cytotoxicity, the metabolic activity of mitochondria of the myeloma cell lines was measured after $72 \mathrm{~h}$ of incubation with PIX in comparison to Dox. PIX dosedependently inhibited the metabolic activity of myeloma cell lines (Fig. 2a). The IC50 for the inhibition was cell linedependent and in the range of $0.5-5 \mu \mathrm{M}$. The cell lines AMO-1 and KMS-12-BM (IC50 at $0.5 \mu \mathrm{M}$ ) were more sensitive to PIX treatment than the other cell lines.

Interestingly, also Dox induced cell-line dependent effects in the myeloma cell lines with KMS-12-BM again as the most sensitive cell line and U-266 with the lowest response to Dox treatment (Fig. 2b).

\section{Effect of PIX on MM cell death}

To further evaluate the cytotoxic activity, flow cytometry analyses were performed $48 \mathrm{~h}$ and 7 days after PIX treatment. After $48 \mathrm{~h}$, a concentration of $0.25 \mu \mathrm{M}$ PIX reduced the viability of the cell line KMS-12-BM to $75.3 \pm 5.4 \%$, whereas $5 \mu \mathrm{M}$ decreased it to $45.4 \pm 6.7 \%$ (data not shown). Apoptosis induction, however, was observed only after a 7-day incubation (Fig. 3). 
Fig. 1 The effect of PIX (a) and Dox (b) on the proliferation of myeloma cell lines (AMO-1, KMS-12-BM, KMS-12-PE, LP1, U-266, OPM-2, RPMI-8226), the stromal cell line HS-5, mesenchymal stem cells (MSC) and activated PBMC from four healthy controls determined by $\left[{ }^{3} \mathrm{H}\right]$-thymidine uptake assay after a 72-h incubation period is shown. Mean proliferation + standard error of at least four experiments is depicted. Proliferation in the absence of PIX and Dox was set at $100 \%$. Statistical significance was determined using the Wilcoxon test $(* p<0.05$ against the untreated control) a

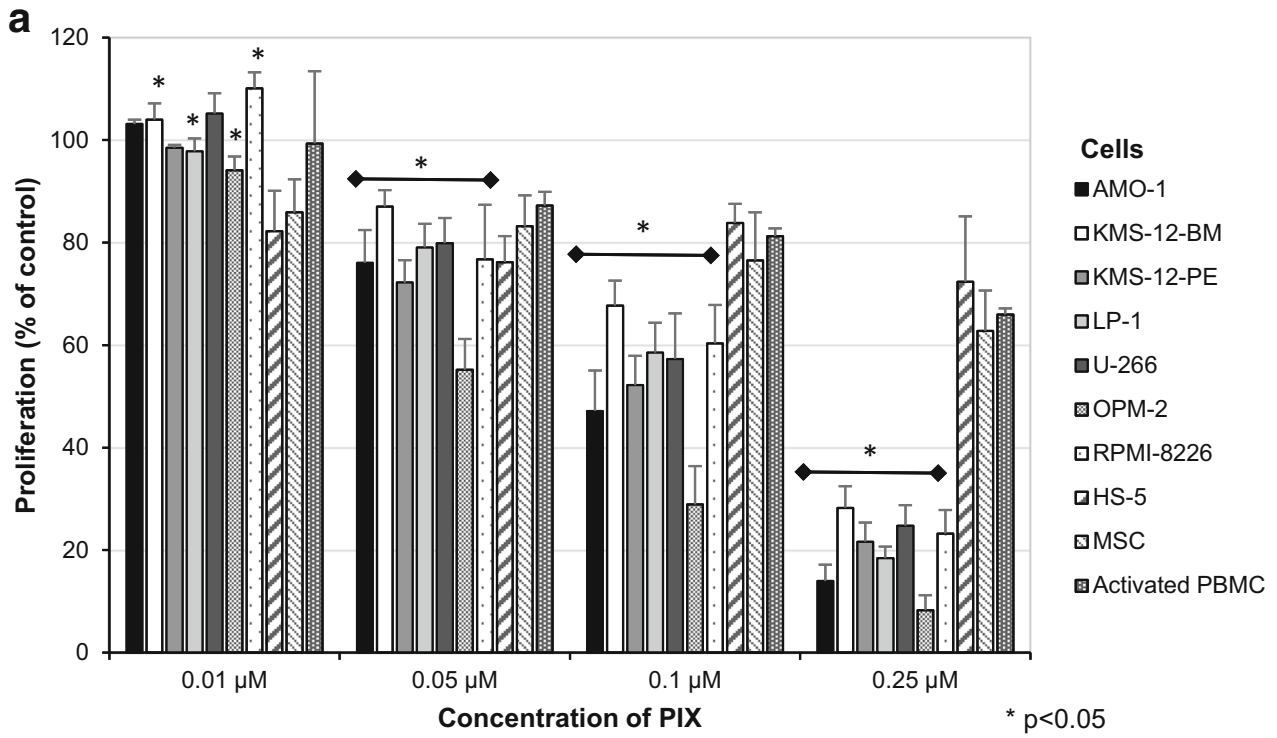

b

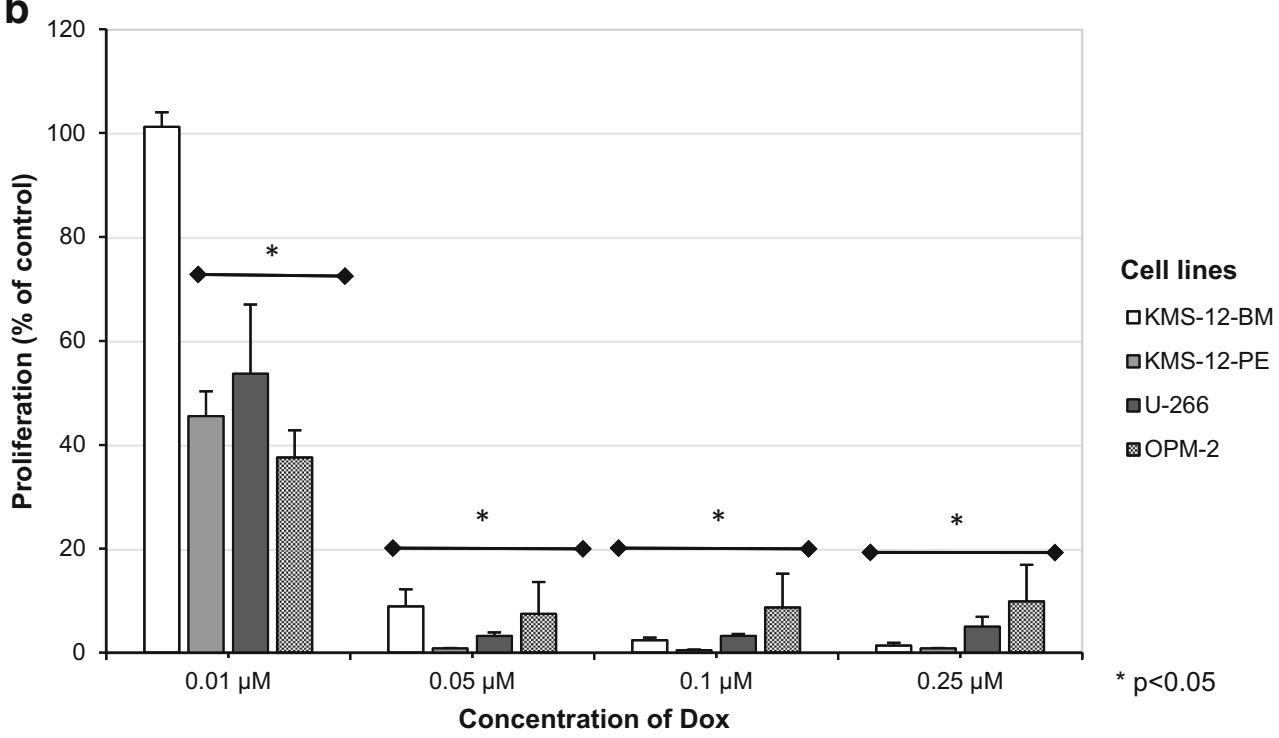

\section{Effect of PIX on myeloma cell growth in a CAM assay}

The strong anti-proliferative activity of PIX combined with its cytotoxic behavior led us to further investigate the action of PIX in an adapted in vivo model, the so-called CAM assay, using GFP-labeled OPM-2 cells and a 5-day incubation period. As shown in a representative example in Fig. 4, PIX (1 $\mu \mathrm{M})$ strongly reduced the growth of the myeloma cells. The tumor load - measured by GFP ELISA - was markedly reduced $(35.0 \pm 7.5 \%$ of control).

\section{Effect of PIX on MM and PCL cells}

The ability of PIX to induce cell death of primary plasma cells from patients was assessed after a 24-h incubation period in vitro. PIX dose-dependently diminished the extent of the cells alive of two patients with refractory relapsed $\mathrm{MM}$ and five patients with de-novo or secondary PCL. At $2.5 \mu \mathrm{M}$, the proportion of plasma cells alive was reduced to $67.9 \pm 10.4 \%$ of control without PIX (Fig. 5a).

FACS analysis was further performed with plasma cells of a patient with refractory relapsed MM analyzing the effect of PIX and Dox at various concentrations and in combination (Fig. 5b). PIX dose-dependently reduced the percentage of cells alive, whereas with $1 \mu \mathrm{M}$ Dox, almost no cells alive were detected any more. At a concentration of $0.25 \mu \mathrm{M}$, PIX and Dox displayed synergistic activity.

\section{Combinatorial activity of PIX}

In most cases, MM patients are treated with a combination triple treatment regimen, whereby a combination of even 
Fig. 2 The effect of PIX (a) and Dox (b) on metabolic activity of MM cell lines after a 72-h incubation period is shown. Mean metabolic activity + standard error of four experiments is depicted. Proliferation in the absence of PIX and Dox was set at $100 \%$. Statistical significance was determined with the

Wilcoxon test $(* p<0.05$ against the untreated control)
Fig. 3 Mean apoptosis induction + standard error of four experiments after an incubation period of 7 days is shown.

Apoptosis in the absence of PIX was set at 1 . Statistical significance was determined with the Wilcoxon test $(* p<0.05$ against the untreated control) a

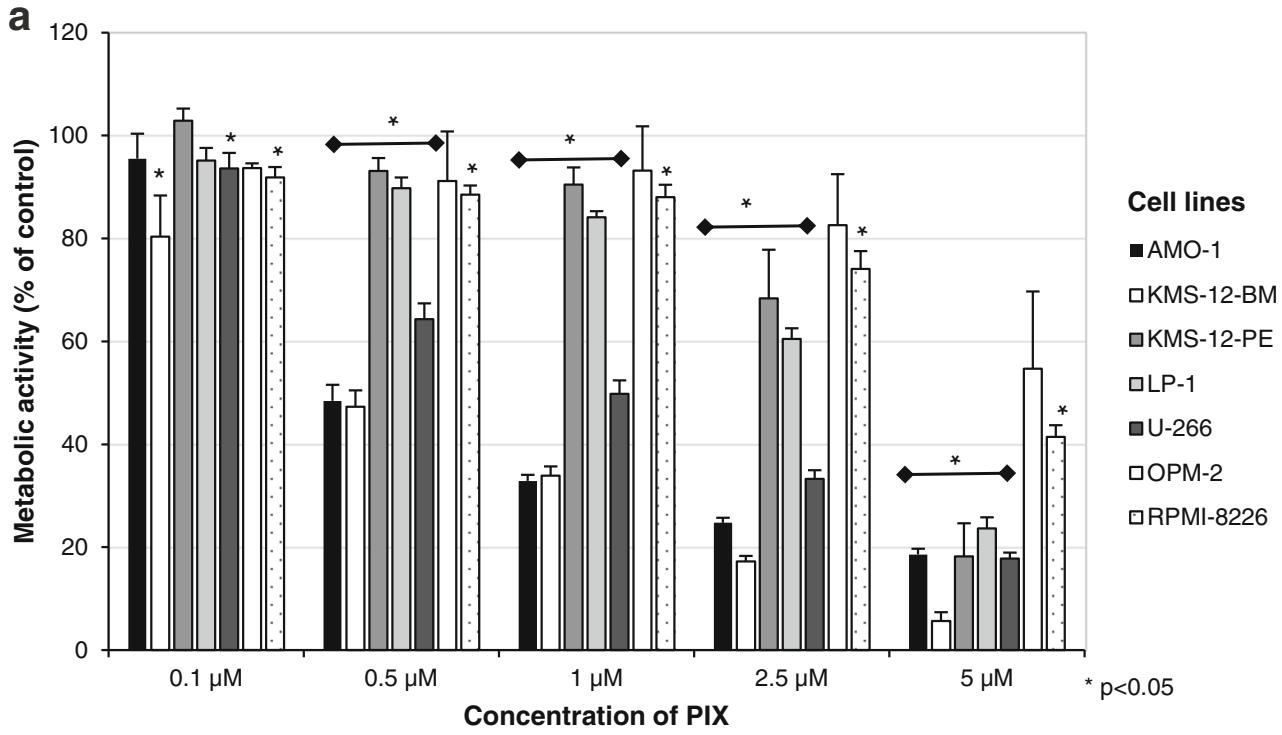

b

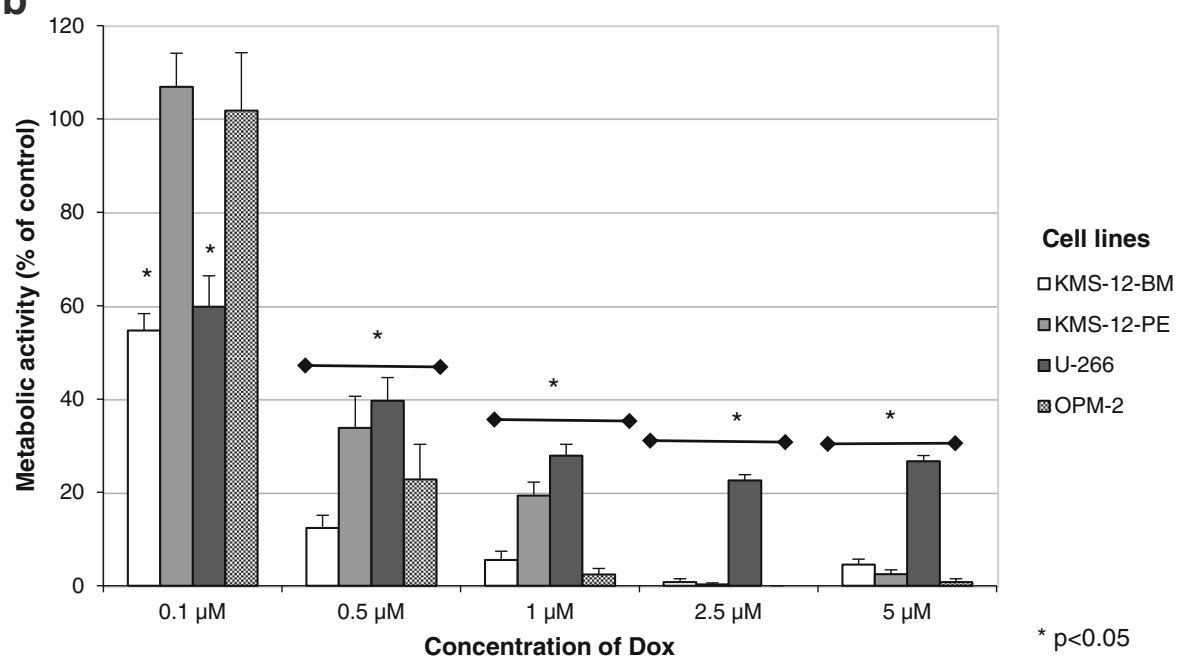


Fig. 4 The effect of PIX in an ex ovo chicken chorioallantoic membrane assay is shown. A representative example of the cell growth of the GFP-labeled myeloma cell line OPM-2 after an incubation period of 5 days with and without $1 \mu \mathrm{M}$ PIX is depicted. Upper view: Transmitted light microscopy, Lower view: GFP staining. Cell growth was determined by GFP ELISA. Mean optical density in the absence of PIX was set at $100 \%$. Mean optical density + standard error of three experiments is depicted

Fig. 5 Mean apoptosis induction, as determined by the decline of the percentage of AnnV/PI negative cells by flow cytometry, + standard error of two patients with de-novo PCL, three patients with secondary PCL and two patients with relapsed refractory $\mathrm{MM}$ (a) after an incubation period of $24 \mathrm{~h}$ with PIX is shown. $\mathbf{b}$ Depicts the percentage of primary cells alive of one patient with relapsed refractory MM incubated for $24 \mathrm{~h}$ with PIX and Dox, respectively. Viability of untreated cells was set at $100 \%$. Statistical significance was determined with the Wilcoxon test $(* p<0.05$ against the untreated control)
Control

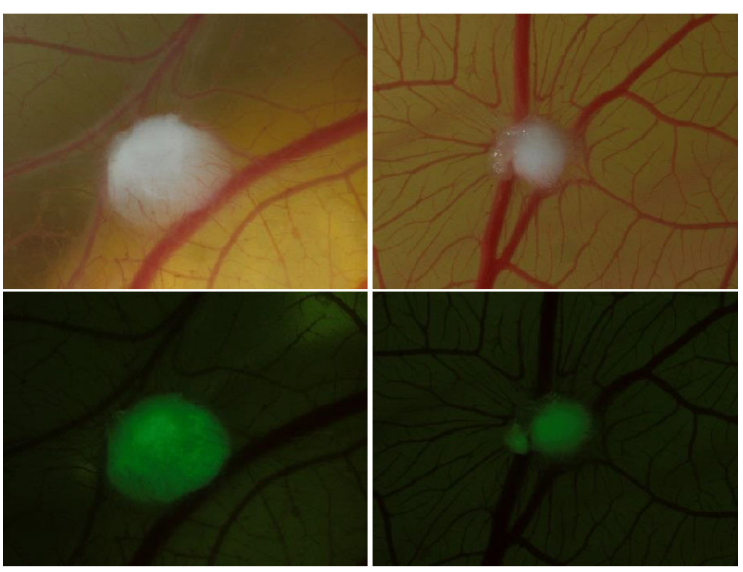

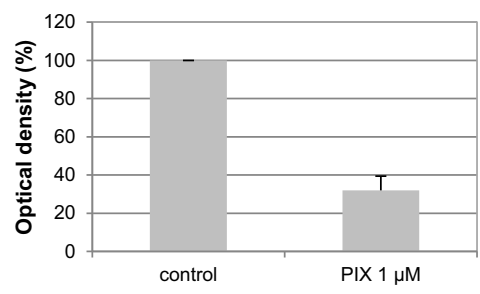

a

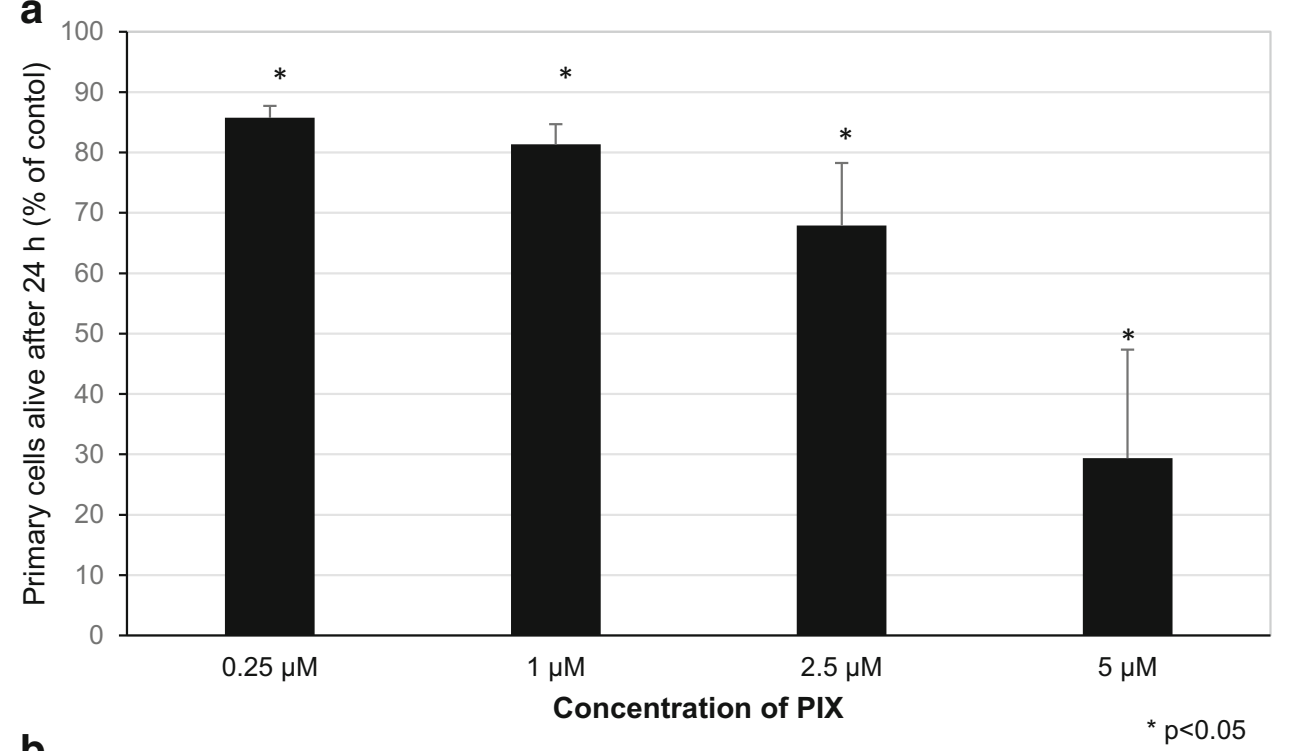

b

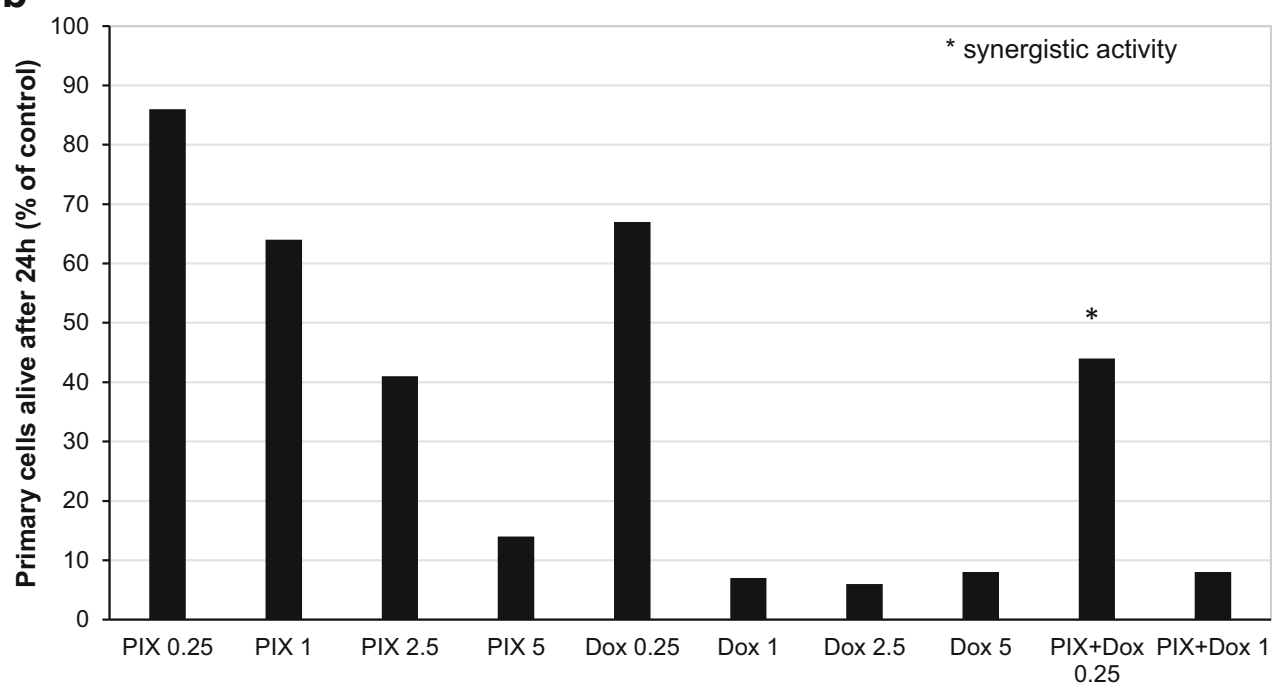

Drugs and concentration $(\mu \mathrm{M})$ 
four drugs is also common. We therefore analyzed proliferation of myeloma cells in response to various sublethal concentrations of PIX (10 nM, $50 \mathrm{nM}, 100 \mathrm{nM})$ in combination with various "new" anti-myeloma compounds such as bortezomib (5 and $10 \mathrm{nM})$, panobinostat ( $3 \mathrm{nM})$, and lenalidomide (10 and $25 \mu \mathrm{M})$ and "classical" $\mathrm{MM}$ drugs such as Dox (10 and $50 \mathrm{nM})$, bendamustine (10 and $50 \mu \mathrm{M}$ ), and dexamethasone (Dex, 10 and 100 $\mu \mathrm{M})$. The most effective combination was PIX $(50 \mathrm{nM})$ and panobinostat (PAN; $3 \mathrm{nM}$ ) (Fig. 6a). This interesting effect was analyzed in more detail by incubating the cell line OPM-2 with $10 \mathrm{nM}$ PIX, $1.5 \mathrm{nM}$ PAN, and $100 \mu \mathrm{M}$ Dex (Fig. 6b). Also at lower concentrations, a synergistic effect between PIX and PAN in inhibiting the proliferation of this myeloma cell line was detected. PIX and Dex displayed synergistic activity, and the three drug combination with PAN also induced a proliferation inhibition of OPM-2 cells.

As already shown for primary cells, PIX $(50 \mathrm{nM})$ and Dox $(50 \mathrm{nM})$ revealed also synergistic effects in the myeloma cell lines suggesting additional mechanisms of these drugs. Similar strong anti-proliferative activity was observed with PIX $(50 \mathrm{nM})$ and bendamustine $(10 \mu \mathrm{M})$.

\section{Discussion}

PIX is approved in the EU for the treatment of aggressive nonHodgkin's lymphoma patients. We therefore investigated if PIX might also be effective in MM and PCL.
Fig. 6 The combinatorial activity of PIX with various anti-MM drugs is depicted. a The following compound concentrations were shown: $50 \mathrm{nM}$ for PIX, $5 \mathrm{nM}$ for bortezomib (BTZ), $3 \mathrm{nM}$ for panobinostat (PAN), $10 \mu \mathrm{M}$ for bendamustine (Benda), $50 \mathrm{nM}$ for doxorubicin (Dox), $10 \mu \mathrm{M}$ for lenalidomide (Lena). b Depicts the following concentrations: 10 $\mathrm{nM}$ for PIX, $1.5 \mathrm{nM}$ for PAN, $100 \mu \mathrm{M}$ for dexamethasone (Dex) a

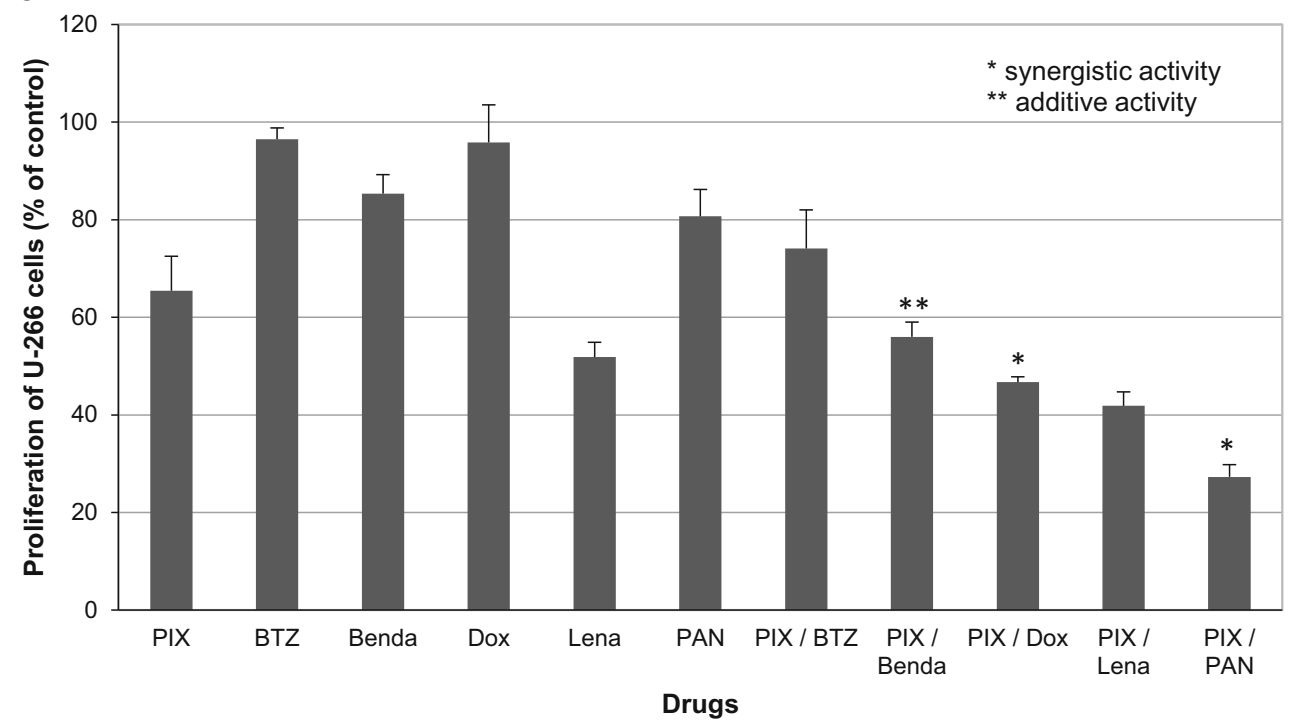

b

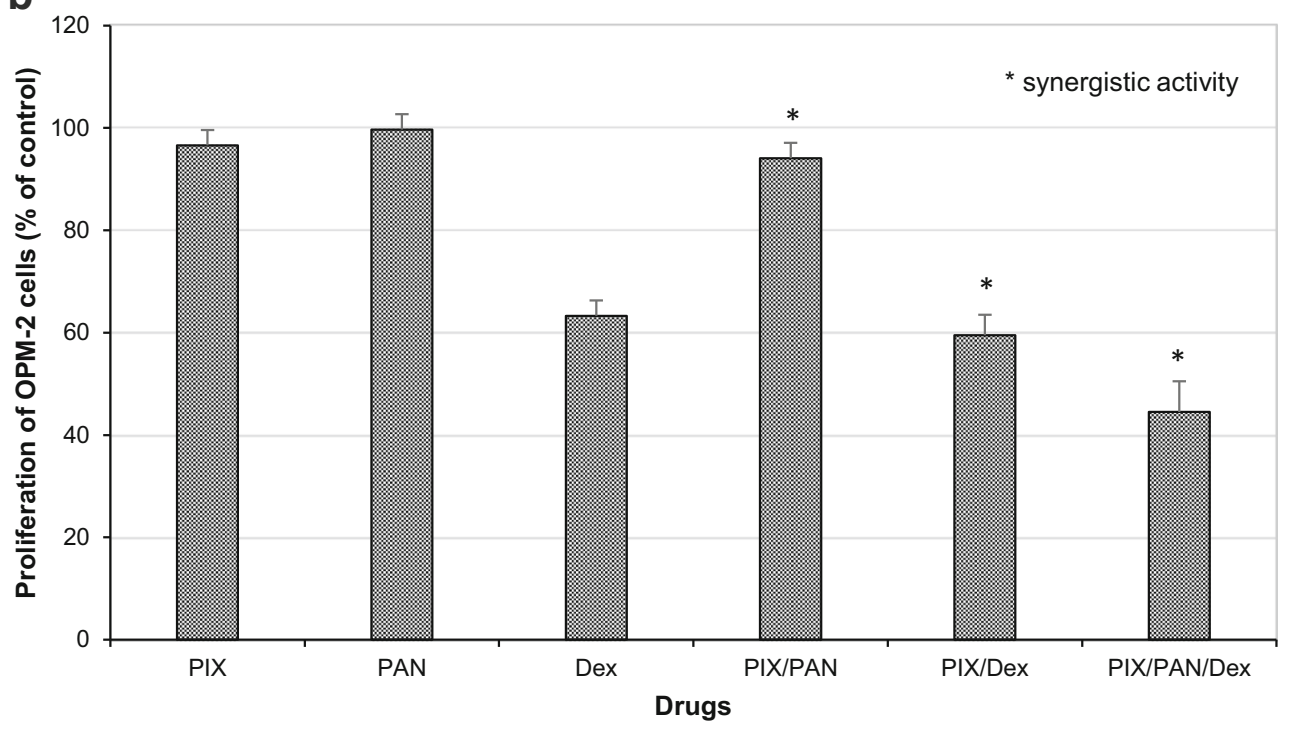


In all cell lines tested, relatively low PIX concentrations (between 0.1 and $0.25 \mu \mathrm{M}$ ) already significantly inhibited cell proliferation. Importantly, a concentration of $0.25 \mu \mathrm{M}$ corresponds to plasma levels achievable with standard-dose PIX in patients [22]. This low dosage needed to induce a cytostatic effect suggests that the use of PIX may be feasible as part of combination therapies in MM and PCL patients.

Importantly, anti-myeloma effects were more pronounced in myeloma cell lines than in the stromal cell line HS-5, MSC, and activated PBMC of healthy controls. The results of the CAM assay further support the putative anti-tumor specificity of PIX while inducing no toxic effect on the embryo.

Inhibition of metabolic activity showed a more variant pattern and may reflect the clinical and biological heterogeneity of this disease. The inhibition of metabolic activity after a 3day culture period was accompanied by apoptosis induction of the MM cell lines after 7 days only, which, nevertheless, is in accordance with the literature [17].

In direct comparison to Dox, higher PIX concentrations were necessary to induce similar strong effects in myeloma cell lines as well as in primary patient cells. However, the improved toxicity profile of PIX $[10,11]$ argues for further studies with PIX.

We were able to demonstrate an impressive in vitro synergism between PIX and PAN with respect to their anti-proliferative features on myeloma cell lines. PAN is a potent, oral pan-deactylase inhibitor that increases acetylation of proteins involved in multiple oncogenic pathways [23]. It has been found to be synergistic with BTZ and Dex in preclinical studies of MM and has shown clinical activity in phase 1,2 , and 3 studies [24, 25]. The PAN-BTZ-Dex regimen demonstrated durable response in relapsed or refractory MM, including BTZrefractory disease [26]. As PIX acts in a deferred way on mitosis [17] and PAN inhibits histone deacetylase [23], a cooperative biological mechanism centered around cell division-associated nuclear processes will be further investigated to increase our understanding of this striking phenomenon. The synergistic activity of PIX, PAN, and Dex might therefore be another treatment option, especially in very advanced MM ("penta-refractory") patients.

Similar strong combinatorial activity was observed with Dox (in cell lines as well as in primary cells) and bendamustine. As at least bendamustine is a good therapeutic option in myeloma therapy-especially in renal failureanother interesting option to be investigated might thus be a bendamustine-PIX combination [27, 28].

In conclusion, PIX induced a strong and fast cytostatic effect in myeloma cell lines and induced apoptosis after a longer incubation period suggesting a putative role of PIX as part of possible combination therapies in relapsed/ refractory $\mathrm{MM}$ and PCL patients in the framework of controlled clinical trials.
Acknowledgments Open access funding provided by University of Innsbruck and Medical University of Innsbruck. The investigational product of this study was donated as a gratuity by CTI Life Sciences (London, UK), the former manufacturer of pixantrone. Panobinostat was also provided by its respective manufacturer (Novartis, $\mathrm{CH}$ ).

Authorship Conception and design BK, WW, EW

Development of methodology BK, BF, KJ

Acquisition of data EW, BF, KJ

Analysis and interpretation of data BK, EW, WW, KJ

Writing, review and/or revision of the manuscript BK, WW, EW, KJ, RG

Study supervision BK, WW, EW

Funding This work was supported by the European Union Seventh Framework Program (FPT7/2007-2013) under grant agreement no. 278570 (OPTATIO) and the SCRI-LIMCR GmbH.

\section{Compliance with ethical standards}

Conflict of interest WW was a member of national and international CTI Life Sciences and Novartis advisory boards, although on subjects unrelated to this research project. The authors $\mathrm{EW}, \mathrm{KJ}, \mathrm{BF}, \mathrm{RG}$, and $\mathrm{BK}$ report no conflicts of interest.

Ethical approval All patients gave written informed consent to the use of their biologic materials for research (EU FP7 consortium OPTATIO) and documentation of their clinical data via the Austrian Myeloma Registry (AMR) after extensive discussion of the respective procedures.

Open Access This article is distributed under the terms of the Creative Commons Attribution 4.0 International License (http:// creativecommons.org/licenses/by/4.0/), which permits unrestricted use, distribution, and reproduction in any medium, provided you give appropriate credit to the original author(s) and the source, provide a link to the Creative Commons license, and indicate if changes were made.

\section{References}

1. Kumar SK, Lee JH, Lahuerta JJ, Morgan G, Richardson PG, Crowley J, Haessler J, Feather J, Hoering A, Moreau P, LeLeu X, Hulin C, Klein SK, Sonneveld P, Siegel D, Blade J, Goldschmidt H, Jagannath S, Miguel JS, Orlowski R, Palumbo A, Sezer O, Rajkumar SV, Durie BG (2012) Risk of progression and survival in multiple myeloma relapsing after therapy with IMiDs and bortezomib: a multicenter international myeloma working group study. Leukemia 26(1):149-157. https://doi.org/10.1038/leu.2011.196

2. Kumar SK, Dispenzieri A, Lacy MQ, Gertz MA, Buadi FK, Pandey S, Kapoor P, Dingli D, Hayman SR, Leung N, Lust J, McCurdy A, Russell SJ, Zeldenrust SR, Kyle RA, Rajkumar SV (2014) Continued improvement in survival in multiple myeloma: changes in early mortality and outcomes in older patients. Leukemia 28(5): 1122-1128. https://doi.org/10.1038/leu.2013.313

3. Willenbacher E, Weger R, Rochau U, Siebert U, Willenbacher W (2016) Real-world use of 3rd Line Therapy for multiple myeloma in Austria: an Austrian Myeloma Registry (AMR) Analysis of the Therapeutic Landscape and Clinical Outcomes prior to the use of next generation myeloma therapeutics. PLoS One 11(3):e0147381. https://doi.org/10.1371/journal.pone.0147381

4. Chng WJ, Dispenzieri A, Chim CS, Fonseca R, Goldschmidt H, Lentzsch S, Munshi N, Palumbo A, Miguel JS, Sonneveld P, Cavo 
M, Usmani S, Durie BG, Avet-Loiseau H (2014) IMWG consensus on risk stratification in multiple myeloma. Leukemia 28(2):269 277. https://doi.org/10.1038/leu.2013.247

5. Moreau P, Cavo M, Sonneveld P, Rosinol L, Attal M, Pezzi A, Goldschmidt H, Lahuerta JJ, Marit G, Palumbo A, van der Holt B, Blade J, Petrucci MT, Neben K, san Miguel J, Patriarca F, Lokhorst H, Zamagni E, Hulin C, Gutierrez N, Facon T, Caillot D, Benboubker L, Harousseau JL, Leleu X, Avet-Loiseau H, Mary JY (2014) Combination of international scoring system 3, high lactate dehydrogenase, and $t(4 ; 14)$ and/or del(17p) identifies patients with multiple myeloma (MM) treated with front-line autologous stem-cell transplantation at high risk of early MM progression-related death. J Clin Oncol : official journal of the American Society of Clinical Oncology 32(20):2173-2180. https://doi.org/10.1200/jco.2013.53.0329

6. Chim CS, Kumar SK, Orlowski RZ, Cook G, Richardson PG, Gertz MA, Giralt S, Mateos MV, Leleu X, Anderson KC (2018) Management of relapsed and refractory multiple myeloma: novel agents, antibodies, immunotherapies and beyond. Leukemia. 32(2): 252-262. https://doi.org/10.1038/leu.2017.329

7. Jelinek T, Kryukov F, Rihova L, Hajek R (2015) Plasma cell leukemia: from biology to treatment. Eur J Haematol 95(1):16-26. https://doi.org/10.1111/ejh.12533

8. Oakervee HE, Popat R, Curry N, Smith P, Morris C, Drake M, Agrawal S, Stec J, Schenkein D, Esseltine DL, Cavenagh JD (2005) PAD combination therapy (PS-341/bortezomib, doxorubicin and dexamethasone) for previously untreated patients with multiple myeloma. Br J Haematol 129(6):755-762. https://doi.org/10. 1111/j.1365-2141.2005.05519.x

9. Orlowski RZ, Nagler A, Sonneveld P, Blade J, Hajek R, Spencer A, San Miguel J, Robak T, Dmoszynska A, Horvath N, Spicka I, Sutherland HJ, Suvorov AN, Zhuang SH, Parekh T, Xiu L, Yuan Z, Rackoff W, Harousseau JL (2007) Randomized phase III study of pegylated liposomal doxorubicin plus bortezomib compared with bortezomib alone in relapsed or refractory multiple myeloma: combination therapy improves time to progression. J Clin Oncol : official journal of the American Society of Clinical Oncology 25(25):38923901. https://doi.org/10.1200/jco.2006.10.5460

10. Knop S, Gerecke C, Liebisch P, Topp MS, Platzbecker U, Sezer O, Vollmuth C, Falk K, Glasmacher A, Maeder U, Einsele H, Bargou RC (2009) Lenalidomide, adriamycin, and dexamethasone (RAD) in patients with relapsed and refractory multiple myeloma: a report from the German Myeloma Study Group DSMM (Deutsche Studiengruppe Multiples Myelom). Blood 113(18):4137-4143. https://doi.org/10.1182/blood-2008-10-184135

11. Hasinoff BB, Wu X, Patel D, Kanagasabai R, Karmahapatra S, Yalowich JC (2016) Mechanisms of action and reduced cardiotoxicity of pixantrone; a topoisomerase II targeting agent with cellular selectivity for the topoisomerase II alpha isoform. J Pharmacol Exp Ther 356(2):397-409. https://doi.org/10.1124/jpet. 115.228650

12. Salvatorelli E, Menna P, Paz OG, Chello M, Covino E, Singer JW, Minotti G (2013) The novel anthracenedione, pixantrone, lacks redox activity and inhibits doxorubicinol formation in human myocardium: insight to explain the cardiac safety of pixantrone in doxorubicin-treated patients. J Pharmacol Exp Ther 344(2):467478. https://doi.org/10.1124/jpet.112.200568

13. Beggiolin G, Crippa L, Menta E, Manzotti C, Cavalletti E, Pezzoni G, Torriani D, Randisi E, Cavagnoli R, Sala F, Giuliani FC, Spinelli S (2001) Bbr 2778, an aza-anthracenedione endowed with preclinical anticancer activity and lack of delayed cardiotoxicity. Tumori 87(6):407-416

14. Srokowski TP, Liebmann JE, Modiano MR, Cohen GI, Pro B, Romaguera JE, Kuepfer C, Singer JW, Fayad LE (2011) Pixantrone dimaleate in combination with fludarabine, dexamethasone, and rituximab in patients with relapsed or refractory indolent non-Hodgkin lymphoma: phase 1 study with a doseexpansion cohort. Cancer 117(22):5067-5073. https://doi.org/10. 1002/cncr.26121

15. Pettengell R, Coiffier B, Narayanan G, de Mendoza FH, Digumarti R, Gomez H, Zinzani PL, Schiller G, Rizzieri D, Boland G, Cernohous P, Wang L, Kuepfer C, Gorbatchevsky I, Singer JW (2012) Pixantrone dimaleate versus other chemotherapeutic agents as a single-agent salvage treatment in patients with relapsed or refractory aggressive non-Hodgkin lymphoma: a phase 3 , multicentre, open-label, randomised trial. The lancet oncology 13(7):696-706. https://doi.org/10.1016/ s1470-2045(12)70212-7

16. Adnan N, Buck DP, Evison BJ, Cutts SM, Phillips DR, Collins JG (2010) DNA binding by pixantrone. Org Biomol Chem 8(23): 5359-5366. https://doi.org/10.1039/c0ob00295j

17. Beeharry N, Di Rora AG, Smith MR, Yen TJ (2015) Pixantrone induces cell death through mitotic perturbations and subsequent aberrant cell divisions. Cancer biology \& therapy 16(9):13971406. https://doi.org/10.1080/15384047.2015.1070979

18. von Metzler I, Heider U, Mieth M, Lamottke B, Kaiser M, Jakob C, Sezer O (2009) Synergistic interaction of proteasome and topoisomerase II inhibition in multiple myeloma. Exp Cell Res 315(14):2471-2478. https://doi.org/10.1016/j.yexcr.2009.04.019

19. Wurtenberger I, Angermaier B, Kircher B, Gust R (2013) Synthesis and in vitro pharmacological behavior of platinum(II) complexes containing 1,2-diamino-1-(4fluorophenyl)-2-alkanol ligands. J Med Chem 56(20):79517964. https://doi.org/10.1021/jm400967z

20. Johrer K, Obkircher M, Neureiter D, Parteli J, Zelle-Rieser C, Maizner E, Kern J, Hermann M, Hamacher F, Merkel O, Wacht N, Zidorn C, Scheideler M, Greil R (2012) Antimyeloma activity of the sesquiterpene lactone cnicin: impact on Pim-2 kinase as a novel therapeutic target. J Mol Med (Berlin, Germany) 90(6):681-693. https://doi.org/10.1007/s00109-011-0848-x

21. Nachbaur DM, Denz HA, Gastl G, Thaler J, Lechleitner M, Braunsteiner H (1989) Combination effects of human recombinant interferon (alpha-2-arg, gamma) and cytotoxic agents on colony formation of human melanoma and hypernephroma cell lines. Cancer Lett 44(1):49-53

22. Pean E, Flores B, Hudson I, Sjoberg J, Dunder K, Salmonson T, Gisselbrecht C, Laane E, Pignatti F (2013) The European Medicines Agency review of pixantrone for the treatment of adult patients with multiply relapsed or refractory aggressive nonHodgkin's B-cell lymphomas: summary of the scientific assessment of the committee for medicinal products for human use. Oncologist 18(5):625-633. https://doi.org/10.1634/theoncologist.2013-0020

23. Atadja P (2009) Development of the pan-DAC inhibitor panobinostat (LBH589): successes and challenges. Cancer Lett 280(2):233-241. https://doi.org/10.1016/j.canlet.2009.02.019

24. Andreu-Vieyra CV, Berenson JR (2014) The potential of panobinostat as a treatment option in patients with relapsed and refractory multiple myeloma. Ther Adv Hematol 5(6):197-210. https://doi.org/10.1177/2040620714552614

25. San-Miguel JF, Einsele H, Moreau P (2016) The role of panobinostat plus bortezomib and dexamethasone in treating relapsed or relapsed and refractory multiple myeloma: A European perspective. Adv Ther 33(11):1896-1920. https://doi.org/10.1007/ s12325-016-0413-7

26. San-Miguel JF, Hungria VT, Yoon SS, Beksac M, Dimopoulos MA, Elghandour A, Jedrzejczak WW, Gunther A, Nakorn TN, Siritanaratkul N, Schlossman RL, Hou J, Moreau P, Lonial S, Lee JH, Einsele H, Sopala M, Bengoudifa BR, Binlich F, Richardson PG (2016) Overall survival of patients with relapsed multiple myeloma treated with panobinostat or placebo plus bortezomib and dexamethasone (the PANORAMA 1 
trial): a randomised, placebo-controlled, phase 3 trial. Lancet Haematol 3(11):e506-e515. https://doi.org/10.1016/s23523026(16)30147-8

27. Ludwig H, Kasparu H, Leitgeb C, Rauch E, Linkesch W, Zojer N, Greil R, Seebacher A, Pour L, Weissmann A, Adam Z (2014) Bendamustine-bortezomib-dexamethasone is an active and welltolerated regimen in patients with relapsed or refractory multiple myeloma. Blood 123(7):985-991. https://doi.org/10.1182/blood2013-08-521468

28. Offidani M, Corvatta L, Maracci L, Liberati AM, Ballanti S, Attolico I, Caraffa P, Alesiani F, Caravita di Toritto T, Gentili S, Tosi P, Brunori M,
Derudas D, Ledda A, Gozzetti A, Cellini C, Malerba L, Mele A, Andriani A, Galimberti S, Mondello P, Pulini S, Coppetelli U, Fraticelli P, Olivieri A, Leoni P (2013) Efficacy and tolerability of bendamustine, bortezomib and dexamethasone in patients with relapsed-refractory multiple myeloma: a phase II study. Blood cancer journal 3:e162. https://doi.org/10.1038/bcj.2013.58

Publisher's note Springer Nature remains neutral with regard to jurisdictional claims in published maps and institutional affiliations. 